\title{
Metanoia in the thinking of Saint John Chrysostom
}

\author{
Fr. Prof. PhD. Vasile RĂDUCĂ \\ Faculty of Orthodox Theology, "Bucuresti” University, \\ ROMANIA \\ E-mail: raducavasile@yahoo.com
}

\begin{abstract}
The present article deals with the Mystery of Repentance and its practice in the thinking of Saint John Chrysostom. Saint John's contribution to the evolution of this Christian practice is exceptional. He is the first Church Father who gave special attention to the spiritual aspect of repentance. In the approach of this aspect, he is similar to what we see in the Father's Apothegms, however, without taking these aspects from there. He had found them in the practice of the Church of Antioch and demonstrated their worth like no one else in his time. This aspect of Saint John Chrysostom's thinking, along with others, highlights his extraordinary personality and quality.
\end{abstract}

Keywords: Repentance, metanoia, sin, restoration, charity, prayer.

\section{Introduction}

Repentance has been a constant practice in the Church, since its beginnings. We know that St. Paul exhorts the Corinthians to examine their conscience before coming to the Lord's Supper. This examination of one's conscience was not going to disappear at some point in time to see it emerging at a certain moment, in the monastic environment as we see in the Apothegms (Sayings) of the Desert Fathers. The apothegms the modern researchers are referring to were put down and collected at the end of the $4^{\text {th }}$ century, or more likely during the first half of the $5^{\text {th }}$ century. The practice of spiritual counseling in the monastic centers is not an invention of those living in those centers, but the practice existed in the Church and was transferred from one monk to the next, without its sacramental character, given the fact that most of the monks were not priests - on the contrary, for a long time the monks represented a category of lay people that were more pious and had more zeal.

I consider that St. John Chrysostom did not have access to these Apothegms, but lived within certain ecclesial communities where repentance was practiced, as a very important current activity in the life of the Church, both under its penitential aspect, and under its psychological-spiritual aspect.

Situating himself along the traditional line of the Church, Saint John Chrysostom considers that metanoia is essential for salvation, given the fact that it supposes a psychological-spiritual change, absolutely necessary in the one who repents, on the one hand, and due to the fact that his behaviour in the ecclesial and social environment will be different from that of someone who considers that he needs no repentance, no continual renewal of his mind and of his behaviour.

Metanoia really supposes a transformation of the way of judging, of judging yourself and of evaluating yourself, first of all according to three landmarks: God, your fellow and your calling as a man. It gives a new dimension to the human soul and a new way of living to him who repents, facilitating his return to the point from which he had drifted away: intimacy with God and with his fellow. 
According to Saint John, repentance is a gift of God and a possibility offered by Him, for us to return not just from the state in which we have fallen by sin, but from the enemy of the human nation to God. Repentance is "a hand held out" that God is offering to us. It is not just a state of spirit and an individual process of return to normality, but a community act and a state of communion in which we involve our fellow by the way we behave with him, reestablishing the communion with him interrupted by the mistakes towards him or by simply involving him into ways of thinking and behaving ill-assorted to those necessary for salvation.

Repentance is the way of re-establishing the communion with God Himself, to Whom we often sin, neglecting the way of the communion with Him, the only certain way to salvation. Helping man to get re-established in the true love to his fellows and to God, repentance shows that within it and by it, man is not alone. He falls alone, yet he gets up helped by others, namely God and his fellow: "Therefore, brothers", says Saint John, "let us offer to ourselves repentance as a redeeming medicine, or rather let us receive from God the repentance that cures us. Because it is not us who are offering it to us, but He Who has given it to us... Consequently, my brothers, let us receive repentance as a medicine unto salvation, let us accept it as a cure that wipes away our sins" [1] (p.170).

Repentance is not just the psychological state someone has reached due to someone's words or due to our own convictions, but also the concrete action that man engages in with his entire personality. "It is not the one [namely the repentance] preached by words, but the one shown in a practical manner, springing from the bottom of the heart and cleaning the dirtiness of sin." [2]

Repentance is not just being sorry for sins, simply crying for having noticed the fall into sin, seeing that "weeping justly expresses the mourning, yet does not lead to straightening" [3], whereas repentance brings the joy of strengthening and the power to speak openly with God $(\pi \alpha \rho \rho \eta \sigma 1 \alpha)$ because God loves, waits and forgives. Repentance situates us in a special freedom, that of being able to speak with responsible courage with God. It makes the tendency of shunning the real dialogue with God and with our fellows disappears from us.

In this sense, St. John says: "God not just does not turn his face away from us when we return to Him, but receives us with a joy by no means smaller than the joy He shows to those who have acquired virtue; He not only does not ask for punishment, but comes Himself to look for those who had been lost, and rejoices much more for finding them than $\mathrm{He}$ rejoices for those who are saved. Therefore, we should not lose our hope when we notice that we are in the category of the sinners and at the same time we should not become daring when we live in virtue. Consequently, when we live piously, we ought to be afraid not to fall because of the trust we have in ourselves, and when we sin, we ought to repent!" [4].

By this text, and others like it, St. John signals that, in this life, the process of moral perfection, which includes the virtuous life and repentance, is not a completed one, but one that is just begun. It supposes risks both for him who accepts the fall, and for him who is endeavoring not to fall, living virtuously. They are both on the way, not at the end of it.

The great stake of repentance is salvation by the real and definitive access to God's Kingdom and, at the same time, by becoming worthy for God to "establish His kingdom" in us. God does not make Himself present in places that are not adequate for His presence, and similarly, in God's Kingdom, a dirty and defiled man cannot enter, says St. John, except after having left out all uncleanliness and evilness. St. John draws the Christians' attention to the fact that the Bridegroom's Father sent away from His Son's wedding the one whose 
clothes were dirty, not "because his clothes were dirty, but because he had entered with these clothes on", he had not given up on what the dirty clothes were symbolizing. "You were", the Lord says, "at the crossroads begging, and I did not turn away from you, ashamed of your poverty, and I did not feel sick because of your lack of honour, I have led you in the mystery room, and have given you the honour of inviting you to the royal dinner and have lifted you up to the heavenly honour, you who deserved the worst punishment. However, with all My benefactions, you have not become any better, but have remained at your evilness, despising both the wedding and the Bridegroom. Go away from Me immediately, and suffer the punishment you deserve for this lack of sensitivity!" [5].

We ought to remember that the help we receive from God has the goal to make us become better. The actual participation to the joy of being present at the Bridegroom's banquet and also the punishment are the logical consequences of the adequacy or lack of adequacy for one or the other state. The Master's intervention is the moment when He signals to everyone for which of the two states he who has been invited at the banquet is adequate and prepared.

In man's straightening by repentance (synonymous with the effort of becoming better), God's mercy is active, but the straightening is not just the effect of God's mercy (in other words, the straightening is not the exclusive product of grace), due to the fact that we only confess the faith in Him, but it also supposes the collaboration between God and man. The weight in this collaboration certainly goes to God, but He is waiting for a small pretext from us (attention, we do not do the beginning, but we offer to God a motivation and justification for His work), to crown us with the liberty $(\pi \alpha \rho \rho \eta \sigma \iota \alpha)$ brought by repentance [6]. "The pretext" that God is waiting for in order to bring on man the fruit of repentance consists in the disposition of man's soul [7] and in his endeavour not to sin again. "Therefore, establish a beginning to your return and everything has been solved. Stop the evilness and do not go down any further in it and you have already acquired everything. For, just as in the case of the diseased, for whom the fact that the illness is not getting worse can be the beginning of the improvement of their health, things are all the same with evilness. Do not get any further in it and evilness will come to an end! And, if you do this for two days, the third day you will go away from it better and, after three days, you will be able to say afterwards twenty days, then, one hundred days and then your whole life. Because, the more you advance, the easier you will see the way and you will stop on the summit and will delight in the good things." [8].

Waiting to receive this "small pretext", God is the One Who will offer to us all we need for our straightening due to his love for men [9]. "The pretext" that God is waiting for takes on two forms: acts worthy of repentance (present both at the beginning and during the repentance process), according to the model of the prodigal son, who returned effectively to the father who was waiting for him and at the same time awaiting the effort made by God Himself for "the lost sheep". In the act of repentance, we are dealing, therefore, with two aspects of the divine-human synergy, in which the weight and the accomplishment of the whole process of restoration of the Christian back to the state from which he fell by sin goes, nevertheless, to God. He awaits and receives benevolently (the case of the prodigal Son) or is looking for the lost one and is putting him on His shoulders, on condition that the latter let God "place him on His shoulders" and bring him to the flock. This is the equivalent of total trust in what God does for man, allowing God to rule in you by everything He does out of love for man: His dominion in you.

The need of repentance is unfortunately imposed by the sins committed by man after his Baptism. Sin is disease. St. John calls it "terrible paralysis or, better said, not just 
paralysis, but also something frightening, because the sinner not just does not do good deeds, but also commits bad deeds" [10].

Repentance for sins is the healing medicine because out of people made of earth, the sinners can become people made of gold [11]. Often the disease of sin can be neglected or regarded with superficiality, ignoring its real consequences and its diverse symptoms, behind which one can find the devil.

\section{The devil and the absence of repentance}

According to St. John, "there is wound, but there is also medicine for it. The wound is $\sin$, the medicine is repentance. Sin means shame, humiliation, it leads us to dishonor, whereas repentance means courage, fasting and offers straightening." [12]

St. John signals other symptoms of sin as well, such as: insensitivity and indifference to the performance of an evil action, shame and sadness (which can lead both to repentance and to losing hope), being sorry without repenting (which can either lead to nothing or can lead to despair). In all these symptoms of sin, is not excluded Satan's power, which by its negative force inhibits in man the tendency to escape the abnormality brought by $\sin$. For this reason, St. John asks himself regarding the sinner who does not take the step towards repentance: why is he not ashamed when he commits the shameful deed, yet he blushes when this deed is signalled to him? In this attitude, St. John sees the deceiving work of the devil. "The enemy does not let man be ashamed the moment he is sinning, but lets him do the sin, and even in front of everyone, because he knows that if man is ashamed, he will avoid sin. When man considers repenting for $\sin$ (because this also supposes confessing sin), the enemy makes him feel ashamed, so that, precisely because of this shame, man will not repent. In this way, the devil acts maliciously under two aspects: drawing man to sin, but also driving him away from repentance" [13].

The devil leads the sinner into a state of spiritual insensitivity, making him insensitive to his precarious spiritual condition, which either will lead him to perdition or will make him lose his hope in God's power to forgive. When man is surrounded by despair from all sides, he gets suffocated [14].

Satan's special effort is to lead man either to spiritual insensitivity, synonymous to what the Scripture often expresses using the expression "petrification of the heart", or to despair. Considering the second state of spirit induced by the devil (despair), St. John exhorts: "never lose hope! This is precisely why the devil does not rejoice so much when we $\sin$ (because repentance may intervene), as when we lose hope" [15].

With the optimism of the one who has known God's love, St. John insists to convince the person fallen into sin that however low sin may take man, it is limited, whereas the almightiness of God's forgiveness is unlimited, so that "God wipes away lawlessness so well that He leaves behind no sign of it, no trace of it, no scar." [16]. "Consequently, St. John will say, are you a sinner? Do not lose hope! I will not stop giving you these medicines forever, as I know how great an arm against the devil it is not to lose hope. But if your sins are burdening you, do not lose hope! I shall not cease saying these words to you, and even if you sin every day, repent every day." [17]

St. John says that in front of repentance and of God's grace there is no sin that will not cease, the moment you want to be good. Surely the devil stops man's impetus towards doing good deeds, yet it has no absolute power because, the Holy Father says, "You have chosen to do good deeds and in this choice you have attracted God as your ally." [18]. 
The condition for God to be man's ally in the fight against Satan and in order for man to do well is that man chooses God himself. "Therefore", says St. John, "God does not want to save you out of necessity and by force, but by your own will... God, Who has made everything not out of His need, but for your salvation, will not want to keep you by force" [19] by His side.

\section{God respects man's self-determination}

God assumed the risk of respect for man's freedom so that, if He were to intervene in his way of self-determination, this would mean an attack against the integrity of his image. It would mean turning His image into something else.

To stimulate man's self-determination, God, says St. John, announces punishments and reward. The objective of these announcements is to bring man to a virtuous life. "If He sees us running away from evilness and coming to the way of virtue and taking care of the good deeds, He will also receive our repentance and, after having delivered us from the burden of our sins, He will offer us His gifts because we do not wish so much our salvation from our sins and we do not ask so much for our salvation as the Lord insists and endeavours to free us from our sins and offer to us the joy of salvation." This salvation is possible, yet only if the Christian shows true repentance, if he moves away from evilness and if he follows the way leading him to virtue. "He who repents and follows God's advice can easily acquire what is good." [20].

Repeatedly, Saint John presents as examples of repentance heroes of the Holy Scripture such as the citizens of Nineveh and King David. Updating the way they repented, St. John offers a true pedagogy of the realization of true repentance, of the obtaining of forgiveness from God and of the full reintegration of the Christian in the community of the Church. "The Church", says St. John, "is the hospital offering forgiveness of sins to those who repent, not the tribunal looking for the guilt for sins". In this way, he highlights the healing character of repentance, and not the penitential one, practiced in a more marked manner in the Western Church. "The Church is more important", says St. John, "than Noah's Ark, because Noah's Ark received the animals and kept them as they were, whereas the Church receives living beings and changes them... There, in the Ark, falcon went in, falcon went out, wolf went in, and wolf went out. Here, in the Church, someone came in falcon and came out pigeon, came in wolf and went out sheep, came in snake and went out lamb, not because he changes his nature, but because his evilness goes away by repentance." [21]

These metaphors have a fantastic force. They underline the work of God's grace, which, really, heals the powerless and completes the incomplete ones. They highlight the fact that repentance, whose aim is to change man for the better, is possible efficiently only in the Church.

Regarding the time of repentance, using the example of David's repentance, St. John says that repentance needs to accompany us throughout our life. Commenting on Psalm 6, verse 6, St. John concludes that King David repented all his life for the sins committed, unlike many of us who, "after having cried for a day and, often, not even for a whole day, we go back to laughter, to the pleasures of a cosy and dissipated life." [22]

Repentance is necessary throughout our life, not just because we always sin and we continually need to change, to renew our mind. "We can be unwavering in good", St. John says, "only after having escaped the waves of this life and reached the peaceful shelter of heaven." [23] 
Repentance can be useless when it is not real and when it is done at a time when it no longer has any effect. An example of useless repentance is the repentance of the rich man in the parable of poor Lazarus and in that of the unreasonable virgins. [24]

St. John signals that the refusal to cry in this life (where our tears bring forth the fruits of salvation) will necessarily make us cry in the future life, yet uselessly. "There [in the other life], crying will be for us an occasion of confusion, here it is a title of glory." [25]

We cannot invoke the faith in God's goodness in order not to repent in this life. God's goodness is real, and so is His mercy, but we cannot invoke God's goodness and mercy to motivate what is missing to us or to sin. "Because God's goodness leads to repentance, not to a greater evil ( $\varepsilon 1 \zeta \mu \varepsilon \tau \alpha v 01 \alpha \sigma \varepsilon \alpha \gamma \varepsilon 1$, оvк $\varepsilon 1 \varsigma \pi \lambda \varepsilon 10 v \alpha \kappa \alpha \kappa \varepsilon 1 \alpha$ ). If you become guiltier due to God's goodness, in this case, instead of honouring, you are rather dishonouring it in front of men; because I see many who are rising against man's justice, so that your reward will be punishment, if you do not use it (God's goodness) in what you ought to. God is a philanthropist, yet He is also a righteous judge. He forgives sins, but he also gives everyone according to his acts. He forgives injustices (sins), wipes away all lawlessness, yet he also weighs the acts justly." [26]

Showing faith in God's goodness, accompanied by a superficial and negligent moral life, is not a proof of honouring God, but rather of dishonouring Him. For this reason, the Christian is invited by the great Church Father to confess God's goodness by a way of living honouring the things believed because living differently from what we believe is falling from faith, with all the consequences coming from here. God's goodness must not be dissociated from His justice.

\section{The steps of repentance}

St. John is very realistic regarding the sins' effects in us. Unfortunately, this is a sad anthropological reality. Advising others on repentance, he does not consider himself immune to sins. On the contrary, he considers himself solidary with all those who need forgiveness by repentance. "I myself", he says, "need healing." However, the Christian must not lose hope, because his Doctor is stronger than the disease caused by sins, so that, even if we were to get to the lowest limit of evilness, He ordains many ways for our salvation.

Out of the ways that God chose for healing our wounds, by the process of repentance, we shall enumerate a few (repeated by St. John in several works), namely:

1. Forgiving our fellow, not just when he makes a mistake, but also when his mistake is the expression of his anger. In other words, our fellow needs to be forgiven when he gets angry and he gets to hurt us. "Because, being people, it is impossible for us not to trespass against others or for others not to trespass against us." [27]

St. John signals that there is nothing else that God hates and condemns more than bitterness against our fellow. This sin has in it something so deadly that, as the Holy Father states, it simply makes the help of the divine mercy cease. [28]

2. Charity. If you do charitable deeds, your sins shall be forgiven, for it is written: Ransom your lawlessness by charitable acts (Daniel 4:24).

3. Prayer. If you pray persistently, you will receive forgiveness, as the example of the widow teaches you, who, by her prayers, changed the heart of the unjust judge. It takes intense and continual prayer, because, if we keep on talking with God, says St. John, the devil can no longer steal our thoughts.

4. Regret for sins and confession of these sins to authorized persons. St. John refers a lot to the practice and to the need to confess one's sins as a stage in the process of 
receiving forgiveness. In his time, the confession was realized privately, not publicly. Regret for sins is considered by St. John as the greatest medicine for sin. Confession with no regret for the injustices committed does not meet the demands of metanoia, but is a simple psychological act. The injustices committed can bring suffering to him who has committed them. This suffering needs to be assumed and accepted with patience, considers St. John: this patience (in suffering) will purify your soul. Patience when evils follow sin and crying for sin are necessary [29], yet to the tears we need to add virtue, as well [30].

5. Mercy and care for the widows and, certainly, for all those in need (Isaiah 1:1718) [31].

From the several ways of realization of repentance, we can see that it needs to be a very complex process of straightening. It is "the furnace in which sins are burnt" [32], but also a repositioning of the human being in his natural dynamism by the cultivation of certain virtues making you worthy of honour again.

Profoundly engaged in the missionary-pastoral activity, St. John deeply understood the role of repentance in the Christian life. No unitary doctrine had been elaborated yet regarding the mystery of repentance; however, he analysed the practice of repentance under all the aspects that the theology of this Holy Mystery will suppose later on. He goes beyond the quite formal and penitential character of the first Christian centuries, highlighting essential aspects of this Mystery, in the direction of which the teaching on repentance will be constituted during the next centuries.

\section{Bibliographic references}

[1]. Out of practical reasons, a part of the references will be cited from the Crestomathy made up of Saint John Chrysostom's works by Father Benedict the Hagiorite (in Romanian: Benedict Aghioritul), entitled "Cuvinte de aur" (Golden Words), vol.VI "Pocăinţa, Spovedania, Postul, Dumnezeiasca Impărtășanie” (Repentance, Confession of Sins, Fasting, Divine Eucharist), translated by Fr.Victor Manolache and edited by Editura Egumeniţa in 2014;

[2]. Despre pocăinţă (On repentance), 7, op.cit., p.171;

[3]. Ibid, 8, p.195;

[4]. Ibid, 1, p.134;

[5]. Omilie la cuvintele "L-am văzut pe Domnul şezând" (Homily on the words "I saw the Lord sitting"), Ibid, p.40;

[6]. Ibid, p.41;

[7]. Eodem loco;

[8]. Comentar la Epistola către Romani (Commentary on the Epistle to the Romans),11, Ibid, p.78;

[9]. Eodem loco:

[10]. Comentar la Evanghelia după Sf. Ev. Matei (Commentary on the Evangel according to the Holy Evangelist Matthew), 66, Ibid, p. 68;

[11]. Ibid, 30 , p.70;

[12]. Despre pocăinţă (On repentance), 8, Ibid, p.189;

[13]. Comentar la Epistola a II-a către Corinteni (Commentary on the Second Epistle to the Corinthians), 22, Ibid, p. 90;

[14]. Despre pocăinţă (On repentance), A, p. 129;

[15]. Ibid, p.128;

[16]. Despre pocăinţă (On repentance), 30, p.194;

[17]. Ibid, 8, p.185;

[18]. Comentar la Evanghelia după Sf. Matei (Commentary on the Evangel according to the Holy Evangelist Matthew), 22, p. 58;

[19]. Ibid, eodem loco; 
[20]. Comentar la Psalmi (Commentary on the Psalms), 12, p. 37;

[21]. Despre pocăinţă (On repentance), 8, apud Benedict Aghioritul, op.cit., p.184;

[22]. Commentary on the Psalms,VI, 3, in Saint Jean Chrysostome, "Euvres complètes" translated by J. Bareille, vol. 3, Paris 1873, p. 614;

[23]. Homilies on the Epistle to the Corinthians, XXIII, "CEuvres...,vol.17, Paris, 1872, p.10;

[24]. Ibid, p .613; Cf. Homilies on Genesis, XLIII, 1, Ibid, vol.VIII, p. 21;

[25]. Ibid, p. 614;

[26]. Commentary on the Epistle to the Ephesians, IV, in Jean Chrysostome, "CEuvres...,vol.18, p. 212;

[27]. Ibid, p. 346; "He who forgives his brother is God's follower". Ibid, Omilia, XVII, 1, pp. 346-347;

[28]. Homilies on Genesis, VIII, 6 "CEuvres..., vol. 7, p. 390;

[29]. Homilies on Psalms, VI, 4 “'Euvres..., vol.8., pp. 615-616;

[30]. Commentary on the Epistle to the Philippians, XIII, "CEuvres..., vol.18, p. 614;

[31]. Homilies on the two Epistles to the Corinthians, XXIII, 4, "CEuvres..., vol.17, p.11;

[32]. Commentary on the Epistle to the Hebrews, 12, P.G. 63, p.159. 